BENM 2021

International Scientific and Practical Conference "Biotechnology, Ecology, Nature Management"

\title{
DEVELOPMENT OF SUGAR COOKIES WITH A PREDISPOSITION TO DISRUPT THE FOLATE CYCLE
}

\author{
Igor A. Nikitin (a)*, Sherzodkhon Mutallibzoda (b), Daria A. Velina (c), \\ Natalia N. Lebedeva (d) \\ *Corresponding author
}

(a) Department of Technology of the Grain Processing, Bakery, Macaroni and Confectionery Industries, Federal State Budget Educational Institution of Higher Education «K.G. Razumovsky Moscow State University of technologies and management (the First Cossack University)», Moscow, Russia, nikitinia@mgutm.ru

(b) Department of Technology of the Grain Processing, Bakery, Macaroni and Confectionery Industries, Federal State Budget Educational Institution of Higher Education «K.G. Razumovsky Moscow State University of technologies and management (the First Cossack University)», Moscow, Russia, mutallibzoda@bk.ru

(c) Department of Technology of the Grain Processing, Bakery, Macaroni and Confectionery Industries, Federal State Budget Educational Institution of Higher Education «K.G. Razumovsky Moscow State University of technologies and management (the First Cossack University)», Moscow, Russia, kattim67@gmail.com

(d) Department of Technology of products from plant raw materials and perfumery and cosmetic products, Federal State Budget Educational Institution of Higher Education «K.G. Razumovsky Moscow State University of technologies and management (the First Cossack University)», Moscow, Russia, n.lebedeva@mgutm.ru

\begin{abstract}
A recipe and technology for the production of fortified biscuits have been developed for consumers with a predisposition to disruption of the folate cycle based on gene polymorphism rs1801133 MTHFR 677C> T, rs 1805087 MTR 2756A> G, rs1801394 MTRR 66A> G. Enrichment of the product with active forms of vitamins $\mathrm{B}_{6}, \mathrm{~B}_{9}, \mathrm{~B}_{12}$ (pyridoxine, methylfolate, methylcobalamin) made it possible to increase the biological value of the product. As a result of the research, a recipe and technology for the production of enriched biscuits of increased biological value, enriched with active forms of vitamins B6, B9, B12 (pyridoxine, methylfolate, methylcobalamin) were developed. It has been proven that the active forms of vitamins are practically not destroyed during baking under the influence of high temperatures. The loss of vitamins was $33.6 \%$ for pyridoxine, $50 \%$ for methylfolate and $86.7 \%$ for methylcobalamin. These losses can be considered acceptable and the dosage of vitamins in the cookie recipe can be adjusted according to them. Due to the presence of active forms of B vitamins in cookies, this product can be recommended for use by people who have a predisposition to a violation of the folate cycle.
\end{abstract}

2672-8575 ㄷ 2022 Published by European Publisher.

Keywords: Cookies, folate cycle, personalized nutrition, vitamins

EY NC ND This is an Open Access article distributed under the terms of the Creative Commons Attribution-Noncommercial 4.0 Unported License, permitting all non-commercial use, distribution, and reproduction in any medium, provided the original work is properly cited. 


\section{Introduction}

The introduction of genomic and post-genomic research technologies into public health practice has shown that a genetic factor can play a significant role in the development of the state of nutritional number in conditions of shortage or inaccessibility of food or significant deficiency (Baturin et al., 2017). Single nucleotide polymorphisms, which arise through mutations with their subsequent spread within a population, are the primary form of genetic diversity. Many of them are associated with nutrition and are receptors for positive selection in the evolutionary process. It should be emphasized that a number of genetic polymorphisms, which originally appeared as a manifestation of adaptation to certain environmental conditions, may in other circumstances act as risk factors for the development of various diseases. For example, polymorphism in the HFE gene leads to a violation of the synthesis of a membrane protein that regulates the absorption of iron, as a result of which all iron supplied with food enters the bloodstream, regardless of the actual needs of the body. In regions where the diet of the population is deficient in iron, the presence of this polymorphism is a positive sign and is fixed in the population. However, in regions rich in iron, this can lead to an overload of the body with this substance and its deposition in the internal organs (Baturin et al., 2012; Willett, 2006).

One of the common genetic polymorphisms associated with a decrease in the level of folate status and the development of a vitamin-deficient state of folic acid is polymorphism of the folate cycle genes. Violation of the folate cycle is discussed in medicine as a possible cause of thrombophilia and cardiovascular diseases, which are based on the problem associated with the metabolism of vitamins $\mathrm{B}_{6}$, $\mathrm{B}_{9}, \mathrm{~B}_{12}$. The results of population studies have shown that the polymorphisms of the rs 1801133 MTHFR 677C $>$ T, rs1805087 MTR 2756A $>$ G and rs1801394 MTRR 66A> G genes, encoding the synthesis of enzymes responsible for folic acid metabolism, are associated with an increased risk of developing these diseases (Baturin et al., 2012; Kim et al., 2012).

To prevent disruption of the folate cycle, it is necessary, first of all, to follow a special dietary diet for the purpose of proper intake of micronutrients in the body (vitamin prevention, limited consumption of foods with a high content of simple carbohydrates) (Dobrolyubov et al., 2006). However, vitamins that enter the body with food are not always enough to fully meet the needs of the body, since in food they are in a form that is indigestible for the carrier of polymorphism. With a mutation in the genes of the folate cycle, the activity of enzymes decreases, which convert the B vitamins into the "active forms" necessary for the body. Vitamins $\mathrm{B}_{6}, \mathrm{~B}_{9}, \mathrm{~B}_{12}$ play a very important role for human health, however, in their usual form, they are unable to penetrate the blood-brain barrier (the barrier between the circulatory and central nervous systems). Only after a number of transformations under the influence of enzymes are these vitamins transformed into active forms (Shikh, 2013). Since these transformations are difficult in people who are carriers of the folate cycle gene polymorphism, they experience a chronic deficiency in the active forms of B vitamins and, as a result, are at increased risk of thrombophilia and cardiovascular diseases. 


\section{Purpose of the Study}

For consumers with disorders of the folate cycle, it becomes necessary to create specialized food products enriched with active forms of vitamins $\mathrm{B}_{6}, \mathrm{~B}_{9}, \mathrm{~B}_{12}$ in order to stop this problem and prevent the development of serious diseases (Ivanova et al., 2019; Karpov et al., 2019).

Cookies are a popular flour confectionery product among the population of the Russian Federation, therefore, it is advisable to enrich these products with the above vitamins. This will allow, on the one hand, to enjoy the pleasant taste of cookies, and on the other hand, to provide the body with biologically active forms of vitamins and prevent the risk of developing diseases.

\section{Research Methods}

At the Department of Technology of the grain processing, bakery, macaroni and confectionery industries, Moscow State University of Technology K.G. Razumovsky (FCU) developed a recipe and technology for the production of cookies for people with a predisposition to disruption of the folate cycle. The active forms of vitamins $\mathrm{B}_{9}, \mathrm{~B}_{12}$ and $\mathrm{B}_{6}$ - methylfolate, methylcobalamin, pyridoxine, which are not part of classic biscuits - were used as fortifiers.

Pyridoxine in the form of its coenzymes is involved in the conversion of amino acids, the metabolism of tryptophan, lipids and nucleic acids, and the maintenance of normal blood homocysteine levels (Kennedy, 2016).

Methylfolate is one of the most active forms of vitamin $\mathrm{B}_{9}$. Unlike folic acid, it is freely absorbed into the circulatory system and consumed by cells (Kennedy, 2016; Radzinskij, 2014).

Methylcobalamin is the active form of vitamin $\mathrm{B}_{12}$. It is used to treat pathologies caused by vitamin $\mathrm{B}_{12}$ deficiency, diseases of the peripheral nervous system, autonomic disorders, and liver pathologies (Fenech, 2011; Fontecilla-Camps et al., 2009).

The production of biscuits consists of the following stages - preparation of the emulsion, kneading the dough, cooling the dough, shaping the dough pieces, baking and cooling the biscuits.

The emulsion is prepared from powdered sugar, eggs and butter. Beat a mixture of eggs and powdered sugar for 3 minutes, then add butter and continue beating for 2 minutes. Flour with baking powder is added to the finished emulsion and the dough is kneaded until a plastic-viscous structure is obtained. Next, the semi-finished product is sent for 20-30 minutes for cooling to the refrigerator and then dough pieces are formed. Baking is carried out at a temperature of $200^{\circ} \mathrm{C}$ for 5 minutes. The finished biscuits are cooled.

The next stage of the work consisted in the study of physical, chemical and organoleptic quality indicators (tables 2, 3).

Determination of organoleptic parameters was carried out according to the following criteria:

1) Smell is an indicator perceived by a person's sense of smell;

2) Taste - reflects the sensations that occur after food affects the taste buds;

3) Shape - correct, not deformed, without kinks, dents, with a smooth edge at the ends;

4) Surface - clear pattern, without swelling, inclusions of crumbs, dimensions should correspond to those indicated in the standard; 
5) Color - the color of the cookie is determined by visual inspection. It should be uniform, characteristic of the name, without burning. Darker coloring of the edges and underside of the cookie is allowed;

6) View on a fracture - with uniform porosity, without voids and traces of impurities.

Determination of physicochemical characteristics was carried out according to the following criteria:

1) Mass fraction of moisture - determined by drying a sample of cookies in an oven, expressed as a percentage;

2) Alkalinity - determined by titrating an infused sample of cookies with a $0.1 \mathrm{~N}$ solution of sulfuric acid. The alkalinity is expressed in degrees. The degree of alkalinity means the amount of $0.1 \mathrm{n}$ acid solution used to neutralize alkalis contained in $100 \mathrm{~g}$ of the product;

3) Wetness (swelling) is the ratio of the mass of biscuits soaked over a certain period of time to the mass of dry biscuits, expressed as a percentage. A good cookie should get wet quickly and significantly in water. To determine the wetness, a three-section cage made of stainless metal mesh with a hole size of no more than $2 \mathrm{~mm}^{2}$ is used. The cage with the cookies is immersed in a vessel with water at a temperature of $20^{\circ} \mathrm{C}$ for 2 minutes. After the excess water has drained off, the cage is weighed along with the wet biscuits. The indicator is expressed as a percentage.

An important stage of the study was the analysis of the safety of the added vitamins in the product.

The preservation of vitamins was determined by high performance liquid chromatography (HPLC).

Liquid chromatography (LC) is a method for the separation and analysis of complex mixtures of substances in which the mobile phase is a liquid. The mobile phase in liquid chromatography has a dual function:

1) provides the transfer of desorbed molecules along the column (similar to the mobile phase in gas chromatography);

2) regulates the equilibrium constants, and, consequently, the retention as a result of interaction with the stationary phase (adsorbed on the surface) and with the molecules of the substances being separated.

The method consists of the following stages - preparation of a mobile phase, preparation of a standard solution, preparation of a test solution, and analysis.

Solution A. About $0.240 \mathrm{~g}$ (accurately weighed) of sodium pentanesulfonate and $5 \mathrm{ml}$ of glacial acetic acid are dissolved in a methanol-water mixture (25:75), transferred to a $250 \mathrm{ml}$ volumetric flask, the volume of the solution is adjusted to the mark with the same solvent and stirred.

Solution B. About $0.275 \mathrm{~g}$ (accurately weighed) of sodium heptanesulfonate and $5 \mathrm{ml}$ of glacial acetic acid are dissolved in a methanol-water mixture (25:75), transferred to a $250 \mathrm{ml}$ volumetric flask, the volume of the solution is adjusted to the mark with the same solvent and mixed.

To obtain a mobile phase, mix solutions A and B in a ratio of 5: 3 .

Preparation of a standard solution. Depending on the composition of the analyzed preparation, a standard solution of vitamins of the considered group contained in this preparation is prepared. Accurate weighed portions of standard samples of vitamins, approximately equal to the content of these vitamins in 
1 tablet (capsule, dose) of the analyzed preparation, are placed in a volumetric flask with a capacity of 50 $\mathrm{ml}, 20 \mathrm{ml}$ of the mobile phase are added, heated for 20 minutes in a water bath at $60^{\circ} \mathrm{C}$, cooled to room temperature, bring the volume of the solution to the mark with the mobile phase and mix.

Preparation of the test solution. Triturate 10 tablets (contents of 10 capsules) and select an exact weighed portion of the powder, approximately equal to the weight of one tablet or the contents of one capsule. When analyzing liquid or gel-like samples, an exact weighed portion is taken, approximately equal to the mass of one dose of the drug. The weighed portion is placed in a $50 \mathrm{ml}$ volumetric flask. Then proceed as in the preparation of a standard solution.

Analysis. The standard and test solutions, previously filtered through a filter with a pore size of 0.5 $\mu \mathrm{m}$, are sequentially chromatographed, detecting at $280 \mathrm{~nm}$. The operation is repeated at least two times.

\section{Findings}

In the work, the physicochemical and organoleptic indicators of the quality of the biscuits are determined. An analysis was carried out for the safety of vitamins in the product. Table 1 shows the recipe for the developed cookie.

Table 1. Formulation of the developed cookie

\begin{tabular}{ccc}
\hline № & Name of the raw material & Quantity \\
\hline 1 & Wheat flour baking of the highest grade & $47,4 \mathrm{~g}$ \\
2 & Powdered sugar & $25,3 \mathrm{~g}$ \\
3 & Butter (72,5\%) & $16,7 \mathrm{~g}$ \\
4 & Chicken egg & $10,6 \mathrm{~g}$ \\
5 & Baking powder & $0,06 \mathrm{~g}$ \\
\hline \multicolumn{1}{c}{ Vitamins } \\
\hline 6 & Vitamin B B $_{6}$ (pyridoxine) & $1900 \mathrm{mcg}$ \\
7 & Vitamin B & $416 \mathrm{mcg}$ \\
8 & Vitamin B $_{12}$ (methylfobate) & $3,5 \mathrm{mcg}$ \\
\hline
\end{tabular}

In the course of experimental research, a cookie recipe was developed with an optimal ratio of raw materials, due to which the product acquires a sweet-creamy taste and aroma.

Next, the organoleptic and physicochemical parameters of the cookies were determined. The results are shown in Tables 2 and 3.

Table 2. Study of the organoleptic characteristics of the developed cookies

\begin{tabular}{ccc}
\hline $\begin{array}{c}\text { Name of the } \\
\text { indicator }\end{array}$ & $\begin{array}{c}\text { Characteristics of the developed } \\
\text { cookies }\end{array}$ & $\begin{array}{c}\text { Characteristics according to GOST } \\
\text { 24901-2014 "Cookies. General } \\
\text { technical conditions" }\end{array}$ \\
\hline Taste and smell & Pronounced, without foreign taste and \\
smell. & $\begin{array}{c}\text { Pronounced, characteristic of the taste } \\
\text { and smell of the components included in } \\
\text { the cookie recipe, without extraneous } \\
\text { taste and smell. }\end{array}$ \\
Form & $\begin{array}{c}\text { Flat, without dents, blisters and } \\
\text { damage to the edge. }\end{array}$ & $\begin{array}{c}\text { Flat, without dents, blisters and damage } \\
\text { to the edge. }\end{array}$ \\
Surface & Smooth, without a pattern & $\begin{array}{c}\text { Smooth, with a clear, not blurred } \\
\text { impression of the pattern on the upper } \\
\text { surface. }\end{array}$
\end{tabular}


Colour

Light straw color

Baked cookies with a uniform porous

View in the break structure, without voids and traces of non-kneading
Uniform, from light straw to dark brown, taking into account the raw materials used. A darker color is allowed for the protruding parts of the relief pattern, the edges of the cookies, the underside and traces of the grid of the oven hearth. Baked cookies with a uniform porous structure, without voids and traces of non-kneading

Table 3. Study of the physico-chemical parameters of the developed cookies

\begin{tabular}{ccc}
\hline $\begin{array}{c}\text { Name of the } \\
\text { indicator }\end{array}$ & $\begin{array}{c}\text { Characteristics of the developed } \\
\text { cookies }\end{array}$ & $\begin{array}{c}\text { Characteristics according to GOST } \\
\mathbf{2 4 9 0 1 - 2 0 1 4} \text { "Cookies. General } \\
\text { technical conditions" }\end{array}$ \\
\hline $\begin{array}{c}\text { Mass fraction of } \\
\text { moisture, } \%\end{array}$ & 4 & no more than 10 \\
Alkalinity, deg. & 1,2 & no more than 2,0 \\
Wetness, $\%$ & 182 & nevertheless 180 \\
\hline
\end{tabular}

As a result of the carried out physicochemical and organoleptic studies, it was revealed that the product meets the requirements of GOST 24901-2014 "Cookies. General technical conditions ".

Since when baking cookies, the temperature on its surface can reach $200^{\circ} \mathrm{C}$, which can lead to partial or complete destruction of vitamins, an analysis was carried out for the preservation of vitamins in the finished cookie. The results of the residual amount of vitamins are presented in table 4 .

Table 4. Results of studies on the preservation of vitamins in cookies

\begin{tabular}{|c|c|c|c|}
\hline \multirow[b]{2}{*}{$\begin{array}{l}\text { Name of the } \\
\text { vitamin }\end{array}$} & \multicolumn{3}{|c|}{ The vitamin content in the product } \\
\hline & $\begin{array}{c}\text { Control } \\
\text { (sample without the } \\
\text { addition of vitamins), } \\
\text { mcg }\end{array}$ & Developed cookies, mcg & $\begin{array}{c}\text { Vitamin losses during } \\
\text { baking, } \%\end{array}$ \\
\hline $\begin{array}{c}\mathrm{B}_{6}, \mathrm{mcg} / 100 \mathrm{~g} \text { of } \\
\text { cookies }\end{array}$ & $150.00 \pm 40.00$ & $1860.00 \pm 280.00$ & 34 \\
\hline $\begin{array}{c}\mathrm{B}_{9}, \mathrm{mcg} / 100 \mathrm{~g} \text { of } \\
\text { cookies }\end{array}$ & $70.00 \pm 30.00$ & $200.00 \pm 40.00$ & 50 \\
\hline $\mathrm{B}_{12,} \begin{array}{c}\mathrm{mcg} / \mathbf{1 0 0} \mathrm{g} \text { of } \\
\text { cookies }\end{array}$ & $0.11 \pm 0.04$ & $0.80 \pm 0.16$ & 87 \\
\hline
\end{tabular}

Two cookie samples were analyzed - a control (no added vitamins) and a developed cookie fortified with active forms of vitamins. The developed biscuit contained more vitamins than the control, despite significant losses of vitamins during baking. The data were taken into account when calculating the dosage of active forms of vitamins in cookies in the future.

\section{Conclusion}

Physicochemical and organoleptic indicators of the quality of the developed biscuits, enriched with active forms of $\mathrm{B}$ vitamins, confirm the high consumer qualities of the product. Studies of the preservation of vitamins in the product have shown that vitamins are partially destroyed during baking, with the exception of methylcobalamin (vitamin $\mathrm{B}_{12}$ ). Despite the losses during baking, the final vitamin content in the developed product is higher than in the sample without added vitamins. 
Thus, as a result of the research carried out, a recipe and technology for the production of fortified biscuits of increased biological value, enriched with active forms of vitamins $\mathrm{B}_{6}, \mathrm{~B}_{9}, \mathrm{~B}_{12}$ (pyridoxine, methylfolate, methylcobalamin), have been developed. It has been proven that the active forms of vitamins are practically not destroyed during baking under the influence of high temperatures. The loss of vitamins was $33.6 \%$ for pyridoxine, $50 \%$ for methylfolate, and $86.7 \%$ for methylcobalamin. These losses can be considered acceptable and the dosage of vitamins in the cookie recipe can be adjusted taking them into account. Due to the presence of active forms of B vitamins in the biscuits, this product can be recommended for use by people who have a predisposition to a violation of the folate cycle.

\section{References}

Baturin, A. K., Sorokina, E. Y., Pogozheva, A. V., \& Tutel'yan, V. A. (2012). Geneticheskie podhody k personalizacii pitaniya [Genetic Approaches to Nutrition Personalization]. Voprosy pitaniya, 81(6), 4-11.

Baturin, A. K., Sorokina, E. Y., Vrzhesinskaya, O. A., Beketova, N. A., Sokolnikov, A. A., Kobelkova, I. V., Keshabyats, E. E., Kodentsova, V. M., Makurina, O. N., \& Peskova, E. V. (2017). Izuchenie svyazi geneticheskogo polimorfizma rs2228570 gena VDR s obespechennost'yu vitaminom D u zhitelej rossijskoj Arktiki [Study of the relationship of the genetic polymorphism pc2228570 of the VDR gene with the provision of vitamin D in the inhabitants of the Russian Arctic]. Voprosy pitaniya, 86(4), 77-84.

Dobrolyubov, A. S., Lipin, M. A., Polyakov, A. V., \& Fetisova, I. N. (2006). Polimorfizmy genov folatnogo obmena i bolezni cheloveka [Polymorphisms of genes of folate metabolism and human disease]. Vestnik novyh medicinskih tekhnologij, 13(4), 71-73.

Fenech, M. F. (2011). Folate (vitamin B9), vitamin B12, and their function in the maintenance of nuclear and mitochondrial genome integrity. Mutation Research: Fundamental and Molecular Mechanisms of Mutagenesis, 733, 21-33. https://doi.org/10.1016/j.mrfmmm.2011.11.003

Fontecilla-Camps, J. C., Amara, P., Cavazza, C., Nicolet, Y., \& Volbeda, A. (2009). Structure-function relationships of anaerobic gas-processing metalloenzymes. Nature, 460, 814-822. https://doi.org/10.1038/nature08299

Ivanova, V. N., Nikitin, I. A., Zhuchenko, N. A., Nikitina, M. A., Sidorenko, Y. I., Karpov, V. I., \& Zavalishin, I. A. (2019). Clustering of multidimensional objects in the formation of personalized diets. International Journal of Advanced Computer Science and Applications, 10(2), 45-50. https://doi.org/10.14569/IJACSA.2019.0100206

Karpov, V. I., Portnov, N. M., Nikitin, I. A., Sidorenko, Y. I., Zavalishin, I. V., Petrov, S. M., Podgornova, N. M., Sidorenko, M. Y., \& Shterman, S. V. (2019). Automated Methodology for Optimizing Menus in Personalized Nutrition. International Journal of Advanced Computer Science and Applications, 10(11), 317-322. https://doi.org/10.14569/IJACSA.2019.0101144

Kennedy, D. O. (2016). B Vitamins and the Brain: Mechanisms, Dose and Efficacy - A Review. Nutrients, 8(2), 1-29. https://doi.org/10.3390/nu8020068

Kim, J., Cho, Y. A., Kim, D.-H., Jeong, J., Lee, B.-H., Hwang, D.-Y., Lee, H.-J., Matsuo, K., Tajima, K., \& Ahn, Y.-O. (2012). Dietary intake of folate and alcohol, MTHFR C677T polymorphism, and colorectal cancer risk in Korea. American Journal of Clinical Nutrition, 95(2), 405-412. https://doi.org/10.3945/ajcn.111.020255

Radzinskij, V. E. (2014). Folaty v XXI veke vne beremennosti [Folate in the 21 st century outside of pregnancy]. StatusPraesens.

Shikh, E. V. (2013). Preimushchestva provedeniya korrektsii folatnogo statusa s ispolzovaniyem vitaminnomineralnogo kompleksa, soderzhashchego metafolin [Benefits of correcting folate status using a vitamin-mineral complex containing metafoline]. Trudnyy patsiyent, 11(8-9), 26-31.

Willett, C. W. (2006). The pursuit of optimal diets: a progress report. Nutritional genomics: discovering the path to personalized nutrition, 37-56. https://doi.org/10.1002/0471781797.ch2 